\title{
Urinary tract infection due to Aeromonas spp., a lesser known causative bacterium
}

\author{
Jharna Mandal', Rahul Dhodapkar ${ }^{2}$, N Srinivas Acharya ${ }^{1}$, Apurba Sastry ${ }^{1}$, Subhash C. \\ Parija ${ }^{1}$ \\ ${ }^{1}$ Department of Microbiology, Jawaharlal Institute of Postgraduate Medical Education and Research \\ (JIPMER), Puducherry, India \\ ${ }^{2}$ Department of Microbiology, Pondicherry Institute of Medical Sciences (PIMS), Puducherry, India
}

Key words: Aeromonas spp;; urinary tract infection; uncommon; uropathogens; Puducherry

J Infect Dev Ctries 2010; 4(10):679-681.

(Received 28 March 2010 - Accepted 02 June 2010)

Copyright $\odot 2010$ Mandal et al. This is an open-access article distributed under the Creative Commons Attribution License, which permits unrestricted use, distribution, and reproduction in any medium, provided the original work is properly cited.

Aeromonas spp. are often associated with diarrhoeal illnesses, soft tissue infections, blood-stream infections leading to sepsis, and intra-abdominal infections, among others [1]. Although Aeromonas was isolated many years ago, evidence implicating this genus as a cause of gastro-intestinal disease in humans has been amassed only since the early 1980s. They are a lesser known cause of urinary tract infection (UTI) and are not known uropathogens. So far there have been few case reports regarding UTI caused by Aeromonas spp. [2-6]. They have also been associated with haemolytic uremic syndrome [3]. Here, we present a series of cases of UTI due to organisms of this genus.

Seven cases of Aeromonas spp. infection were reported to the Jawaharlal Institute of Postgraduate Medical Education and Research (JIPMER) hospital, Puducherry, between 2007 and 2009. All the cases were from different wards and outpatient departments with no observable common link between any cases. All of our patients had attended different clinics at different times and in different departments. No gender or age group trend was noted; five cases were below 50 years of age, while one case was above 60 years and one was below five years of age. Three patients were treated on an outpatient basis, while four required hospital admission (see Table). Urine samples from suspected cases of UTI received in the laboratory were subjected to culture onto cysteine lactose electrolyte deficient medium (CLED) by the semi-quantitative technique and microscopic examination. Four of the samples had demonstrable significant pus cells while three samples did not have any pus cells; the latter three cases presented with significant bacteriuria and the organism was isolated in pure culture. The CLED plates were examined after an incubation period of 18 to 24 hours and processed [7] per recommendations. Significant bacterial isolates were identified according to standard methods [7] and antimicrobial susceptibility testing was performed by the Kirby Bauer method according to the Clinical Laboratory Standards Institute guidelines [8]. All of our Aeromonas isolates were obtained in pure culture [9]. The biochemical tests applied were aesculin hydrolysis, Voges-Proskauer reaction, lysine decarboxylase, ornithine decarboxylase, arginine hydrolysis, indole production, and production of acid and gas from fermentation of glucose, arabinose, mannitol, and sucrose. Four of the strains were identified as Aeromonas caviae, two strains as Aeromonas veronii, and one as Aeromonas schubertii. We have isolated these strains from samples of different patients in different units and at different times; therefore we are confident they were not contaminants. Moreover, the same strain was isolated on more than one occasion from some of the patients; for instance, as in 
Table. Details of the cases with UTI due to Aeromonas spp.

\begin{tabular}{|c|c|c|c|c|c|}
\hline \multirow{2}{*}{ Age/sex } & \multirow{2}{*}{$\begin{array}{l}\text { Inpatient/ } \\
\text { Outpatient; } \\
\text { Department }\end{array}$} & \multirow{2}{*}{$\begin{array}{c}\text { Clinical } \\
\text { Diagnosis }\end{array}$} & \multirow{2}{*}{$\begin{array}{c}\text { Culture } \\
\text { Isolate } \\
\text { identification } \\
\end{array}$} & \multicolumn{2}{|c|}{ Antibiotic susceptibility pattern } \\
\hline & & & & Resistant & Sensitive \\
\hline $\begin{array}{l}36 \text { years/ } \\
\text { Female }\end{array}$ & $\begin{array}{l}\text { Inpatient; } \\
\text { Internal } \\
\text { Medicine }\end{array}$ & UTI & $\begin{array}{c}\text { Aeromonas } \\
\text { caviae }\end{array}$ & Ciprofloxacin & $\begin{array}{l}\text { Amikacin, Gentamicin, } \\
\text { Ceftriaxone, } \\
\text { ceftazidime,Nitrofurantoin, } \\
\text { Meropenem }\end{array}$ \\
\hline $\begin{array}{l}35 \text { years/ } \\
\text { Female }\end{array}$ & $\begin{array}{c}\text { Inpatient; } \\
\text { Obstetrics \& } \\
\text { Gynaecology }\end{array}$ & $\begin{array}{l}\text { Preterm } \\
\text { labour }\end{array}$ & $\begin{array}{c}\text { Aeromonas } \\
\text { veronii }\end{array}$ & None & $\begin{array}{l}\text { Amikacin, Gentamicin, } \\
\text { Ceftriaxone, Ceftazidime, } \\
\text { Ciprofloxacin, } \\
\text { Nitrofurantoin, } \\
\text { Meropenem }\end{array}$ \\
\hline $\begin{array}{l}44 \text { years/ } \\
\text { Female }\end{array}$ & $\begin{array}{c}\text { Outpatient; } \\
\text { Urology }\end{array}$ & $\begin{array}{l}\text { Left renal } \\
\text { calculus }\end{array}$ & $\begin{array}{c}\text { Aeromonas } \\
\text { schubertii }\end{array}$ & None & $\begin{array}{l}\text { Amikacin, Gentamicin, } \\
\text { Ceftriaxone, ceftazidime, } \\
\text { Ciprofloxacin, } \\
\text { Nitrofurantoin, } \\
\text { Meropenem }\end{array}$ \\
\hline $\begin{array}{l}25 \text { years/ } \\
\text { Male }\end{array}$ & $\begin{array}{c}\text { Inpatient; } \\
\text { Urology }\end{array}$ & $\begin{array}{l}\text { Post } \\
\text { urethroplasty }\end{array}$ & $\begin{array}{c}\text { Aeromonas } \\
\text { caviae }\end{array}$ & None & $\begin{array}{l}\text { Amikacin, Gentamicin, } \\
\text { Ceftriaxone, Ceftazidime, } \\
\text { Ciprofloxacin, } \\
\text { Nitrofurantoin, } \\
\text { Meropenem }\end{array}$ \\
\hline $\begin{array}{c}63 \text { years/ } \\
\text { Male }\end{array}$ & $\begin{array}{l}\text { Outpatient; } \\
\text { General } \\
\text { surgery }\end{array}$ & $\begin{array}{l}\text { Periurethral } \\
\text { abscess }\end{array}$ & $\begin{array}{c}\text { Aeromonas } \\
\text { veronii }\end{array}$ & None & $\begin{array}{l}\text { Amikacin, Gentamicin, } \\
\text { Ceftriaxone, Ceftazidime, } \\
\text { Ciprofloxacin, } \\
\text { Nitrofurantoin, } \\
\text { Meropenem }\end{array}$ \\
\hline $\begin{array}{c}46 \text { years/ } \\
\text { Male }\end{array}$ & $\begin{array}{c}\text { Outpatient; } \\
\text { Urology }\end{array}$ & $\begin{array}{c}\text { Pelvi- } \\
\text { ureteric } \\
\text { junction- } \\
\text { obstruction }\end{array}$ & $\begin{array}{c}\text { Aeromonas } \\
\text { caviae }\end{array}$ & $\begin{array}{l}\text { Gentamicin, } \\
\text { Nitrofurantoin, } \\
\text { Ceftriaxone }\end{array}$ & $\begin{array}{l}\text { Amikacin, Ceftazidime, } \\
\text { Ciprofloxacin, } \\
\text { Meropenem }\end{array}$ \\
\hline $\begin{array}{l}4 \text { years/ } \\
\text { Female }\end{array}$ & $\begin{array}{l}\text { Inpatient; } \\
\text { Pediatrics }\end{array}$ & $\begin{array}{l}\text { UTI with } \\
\text { chronic renal } \\
\text { failure }\end{array}$ & $\begin{array}{c}\text { Aeromonas } \\
\text { caviae }\end{array}$ & Ciprofloxacin & $\begin{array}{l}\text { Amikacin, Gentamicin, } \\
\text { Ceftriaxone, Ceft-zidime, } \\
\text { Nitrofurantoin, } \\
\text { Meropenem }\end{array}$ \\
\hline
\end{tabular}

patient 4, who was admitted in the hospital and had submitted more than one sample. Samples were also sent for culture after completion of an antibiotic course in two patients, which showed the urine to be sterile.

Recently, members of the genus Aeromonas have been increasingly recognized as important human pathogens. Their changing phylogenetic relationship, evolving taxonomy, and controversial role in human disease have been a matter of concern. Currently, there are 14 valid genomospecies in the genus Aeromonas that are best differentiated by molecular methods [1]. The pathogenesis of urinary tract infection due to Aeromonas spp. has not been elucidated in any of the available literature; however, they are known to produce a number of putative virulence factors such as fimbriae and haemolysin [5]. These organisms can affect any age group. There have been reports of vaginal colonization with Aeromonas from normal pregnant females [10] and patients in labour [11].

Clinically relevant Aeromonas spp. are uniformly resistant to many beta lactams such as penicillin and ampicillin and they are known to produce many beta-lactamases. Aminoglycosides are usually active against this genus, though resistance has been reported.

Fluoroquinolones are highly active against Aeromonas spp., although nalidixic acid resistance $[5,6]$ and carbapenem resistance have also been reported [12]. In the present study, two of the isolates of A. caviae were resistant only to ciprofloxacin; one strain was resistant to nitrofurantoin, gentamicin, and ceftriaxone; and one strain was sensitive to all 
the antibiotics tested (amikacin, genatmicin, nitrofurantoin, ciprofloxacin, ceftriaxone, ceftazidime, and meropenem). Both the isolates of $A$. veronii and $A$. schubertii were sensitive to all of the antibiotics.

The niche of Aeromonas is mainly marine water sources and Puducherry is a coastal city, flanked by the Bay of Bengal to the east. In our patients, we did not look for this epidemiological link. Although it is an uncommon uropathogen, the likelihood of its isolation from unusual sites, especially in coastal regions, cannot be overemphasized.

\section{References}

1. Abbott SL, Cheung WK, Janda JM (2003) The genus Aeromonas: biochemical characteristics, atypical reactions, and phenotypic identification schemes. J Clin Microbiol 41: 2348-57.

2. Bartolome RM, Andreau A, Xercavins M, Elcuaz R, Salcedo S (1989) Urinary tract infection by Aeromonas hydrophila in a neonate. Infection 17: $172-3$.

3. Hsueh PR, Teng LJ, Lee LN, Yang PC, Chen YC, Ho SW, Luh KT (1998) Indwelling device-related and recurrent infections due to Aeromonas species. Clin Infect Dis 26: 651-8.

4. Hua HT, Bollet C, Tercian S, Drancourt M, Raoult D (2004) Aeromonas popoffii urinary tract infection. J Clin Microbiol 42: 5427-8.

5. Al-Benwan K, Abbott S, Janda JM, Huys G, Albert MJ (2007) Cystitis Caused by Aeromonas caviae. J Clin Microbiol 45: 2348-50.

6. Ojeda-Vargas M, González-Fernández MA, Alfonso-Rodríguez O, Monzón-Moreno C (2005) Urinary tract infection caused by bacteria of the genus Aeromonas .Enferm Infecc Microbiol Clin 23: 181-2.

7. Collee JG, Duguid JP, Fraser AG, Marmion BP, Simmons A (1999) Urinary tract infections. Laboratory strategy in the diagnosis of infective syndromes. In: Collee JG, Fraser AG, Marmion BP, Simmons A (editors). Mackie \& McCartney: Practical Medical Microbiology. Edinburgh: Churchill Livingstone, pp 84-90.

8. Clinical Laboratory Standards Institute (2005) Performance standards for antimicrobial disk susceptibility tests. Approved standard M2-A9. National Committee for Clinical Laboratory Standards, Wayne, PA.

9. Old DC (1999) Vibrio, Aeromonas, Plesiomonas, Campylobacter, Arcobacter, Helicobacter, Wolinella. In: Collee JG, Fraser AG, Marmion BP, Simmons A (editors) Mackie \& McCartney: Practical Medical Microbiology. , Edinburgh: Churchill Livingstone pp 425-48.

10. Damiain RF, Zesati RV, Fernandez LS, Garcia JLA (1995) Septicemia due to Aeromonas hydrophila in a Pregnant Woman: A Case Report and Review of the Literature. Infectious Diseases in Obstetrics and Gynecology 3: 252-5.

11. Ekwempu CC, Lawande RV, Egler LJ (1981) Microbial flora of the lower genital tract of women in labour in Zaria, Nigeria. J Clin Pathol 34: 82-3.

12. Sánchez-Céspedes J, Figueras MJ, Aspiroz C, Aldea MJ, Toledo M, Alperí A, Marco F, Vila J (2009) Development of imipenem resistance in an Aeromonas veronii biovar sobria clinical isolate recovered from a patient with cholangitis. J Med Microbiol 58: 451-5.

\section{Corresponding author}

Dr. Subhash Chandra Parija MD, PhD, DSc, FRCPath Professor and Head

Department of Microbiology

JIPMER, Puducherry- 605006

India

Telephone: 91 -413-2279214

Tele fax: 91 -413-2272067

Email: subhashparija@yahoo.co.in

Conflict of interests: No conflict of interests is declared. 